\title{
Sistem Informasi Penjualan Kredit Barang Berbasis Vb.Net Pada Pd Ria Mulya Karawang
}

\author{
Arif Maulana Yusuf ${ }^{1, *}$, Indaryono1, Juwita Novita Sari² \\ ${ }^{1}$ Program Studi Komputerisasi Akuntansi, STMIK Rosma, Karawang, Indonesia \\ Email: 1," arif@rosma.ac.id, ${ }^{1}$ indaryono@dosen.rosma.ac.id, ${ }^{2}$ juwita@mhs.rosma.ac.id
}

\begin{abstract}
Abstrak - Aktifitas penjualan kredit barang pada Pd Ria Mulya Karawang merupakan salah satu proses perusahaan yang bergerak dibidang penjualan peralatan rumah tangga. Dalam hal penjualan kredit dan penjualan cash. Untuk meningkatkan dana perusahaan, diberlakukan kepada setiap customer yang melakukan pembelian secara kredit dikenakan bunga yang diharapkan dalam kurun waktu beberapa bulan, dana-dana yang diperoleh dari bunga ini dapat memperbesar pendapatan perusahaan. Tujuan dari penelitian ini adalah untuk mengetahui sistem penjualan kredit barang yang sedang berjalan pada PD Ria Mulia Karawang seperti apa. Metodologi yang digunakan dalam penelitian ini meliputi Analisa Sistem, Perancangan Sistem, dan Implementasi Sistem. Analisa Sistem dalam bahasa, hal ini meliputi Analisa Sistem yang Berjalan dan Analisa Masalah serta Solusi. Perancangan Sistem meliputi Perancangan Masukan, Keluaran, Proses dan Database. Metode implementasi sistem meliputi penyusunan program dan tes program. Dalam penyelenggaraan penjualan kredit barang ini secara administratif belum sepenuhnya dilaksanakan dengan baik. Seperti aktivitas pencatatan data penjualan kreditnya ini masih ditemukan adanya kendala seperti pembuatan laporan penjualannya dilakukan dengan merekap data pada buku penjualan. Berdasarkan permasalan tersebut diatas, penulis berpendapat bahwa untuk mengatasi permasalahan yang terjadi tersebut, perlu dirancang dan diimplementasikan suatu sistem yang terintegrasi antar fungsi-fungsi yang terkait dalam perusahaan, dengan menggunakan microsoft visual basic.net 2008 dan SQL Server 2008 sebagai databasenya. Dengan menerapan sistem ini diharapkan akan dapat bermanfaat bagi perusahaan dalam operasionalnya dimasa yang akan datang.
\end{abstract}

Kata Kunci: Penjualan Kredit, VB .Net, Sql Server, Sistem, Perusahaan

Abstract-The activity of selling goods credit at Pd Ria Mulya Karawang is one of the processes of a company engaged in the sale of household appliances. In terms of credit sales and cash sales. To increase company funds, every customer who makes purchases on credit applies to the expected interest within a few months, the funds obtained from this interest can increase the company's income. The purpose of this study was to determine what kind of credit sales system that is currently running at PD Ria Mulia Karawang. The methodology used in this research includes System Analysis, System Design, and System Implementation. System Analysis in language, this includes Analysis of Current Systems and Analysis of Problems and Solutions. System Design includes Designing Inputs, Outputs, Processes and Databases. System implementation methods include programming and program testing. In the administration of the sale of credit goods, administratively, it has not been fully implemented properly. Such as the activity of recording credit sales data, there are still obstacles such as making sales reports done by recapitulating the data in the sales book. Based on the aforementioned problems, the authors argue that in order to overcome the problems that occur, it is necessary to design and implement an integrated system between related functions within the company, using Microsoft Visual Basic.net 2008 and SQL Server 2008 as the database. By implementing this system, it is hoped that it will be useful for the company in its operations in the future.

Keywords: Credit Sales, VB .Net, Sq1 Server, System, Company

\section{PENDAHULUAN}

\subsection{Latar Belakang}

Penjualan merupakan sumber dari pendapatan perusahaan, dimana semakin besar penjualan maka mampu menguntungkan perusahaan dengan pendapatan yang semakin besar pula[1]. Perusahaan tidak mampu untuk berkembang ketika dalam penjualan produk yang dihasilkan tidak mampu untuk berkompetisi dengan pesaing. Penjualan dianggap sebagai ujung tombak suatu perusahaan dalam memasarkan suatu produk kepada konsumen. Oleh karena itu setiap perusahaan harus mampu mengawasi pelaksanaan penjualan dalam perusahaan itu dengan baik sehingga kegiatan penjualan dapat terkendali dan dapat memaksimalkan keuntungan bagi perusahaan[2]. Selain mempunyai sistem penjualan yang baik, perusahaan juga harus memiliki sistem penagihan piutang yang baik karena banyak perusahaan pengguna barang membutuhkan waktu dalam melakukan pembayaran pada saat konsumen membeli barang dalam jumlah dan harga yang tidak sedikit. Piutang merupakan aktiva yang paling penting dalam perusahaan dan dapat menjadi bagian yang besar dari likuiditas perusahaan[3]. Apabila piutang terhambat maka akan mengakibatkan kesulitan bagi perusahaan dalam mengelola aktivitas perusahaan seharihari[4]. Hal ini disebabkan kurang adanya dana tunai berupa jumlah aktiva lancar yang tersedia secara cukup untuk menunjang keperluan operasi perusahaan[5].

PD Ria Mulia Karawang merupakan perusahaan yang bergerak dibidang penjualan peralatan rumah tangga, elektronik dan lain-lain. Barang yang ditawarkan PD Ria Mulia Karawang berupa Badcover, Sprei dengan 
berbagai macam merk, kulkas dan lain-lain. Awal berdirinya PD Ria Mulia Karawang hingga saat ini dalam penawarannya atau pemasarannya masih memasarkan barang-barangnya tersebut dengan cara manual atau door to door yang dilakukan oleh sales. Sales menawarkan barang dagangnya kepada customer dengan cara membawa barang dagannya secara langsung. Seiring dengan perkembangan dan keinginan masyarakat untuk memiliki suatu barang dengan cepat dan mudah, maka PD Ria Mulia Karawang menerapkan sistem penjualan barang secara kredit selama sepuluh bulan, karena dengan penjualan secara kredit ini PD Ria Mulia Karawang berharap penjualannya akan dapat lebih meninggkat.

Pada saat ini sistem penjualan barang secara kredit yang ada pada PD Ria Mulia Karawang yaitu masih menggunakan sistem manual, dimana dalam proses pengolahan datanya PD Ria Mulia Karawang masih melakukan pencatatan data penjualan kreditnya masih dilakukan dalam bentuk pencatatan pada pembukuan dan nota, pembuatan laporan ini membutuhkan waktu yang relatif lama, karena pembuatan laporan ini dilakukan dengan merekap data pada buku penjualan. Masalah keamanan dalam penyimpanan data, pengarsipan data yang tidak teratur sehingga mengakibatkan data rentan hilang.

Oleh karena itu, untuk mengatasi permasalahan diatas perusahaan dapat melakukan pengembangan sistem. Penulis tertarik untuk membuat rancangan dengan menggunakan Microsoft Visual Basic.net 2008 dan database SQL Server 2008, dengan harapan dari hasil penelitian ini dapat meminimalisir kesalahan pencatatan, serta kecepatan dan ketepatan dalam mengolah informasi terhadap PD Ria Mulia Karawang.

\subsection{Rumusan Masalah}

Berdasarkan latar belakang diatas penulis dapat merumuskan masalah sebagai berikut: Bagaimana merancang penjualan kredit agar pendataannya lebih cepat saat melakukan pencariaan datanya dibanding dengan cara manual.

\subsection{Ruang Lingkup}

Ruang lingkup yang akan dibahas antara lain adalah sebagai berikut:

a. Mengidentifikasi prosedur penerimaan pesanan dari pelanggan pada PD Ria Mulia Karawang.

b. Mengidentifikasi prosedur penjualan kredit pada PD Ria Mulia Karawang.

c. Mengidentifikasi prosedur penagihan piutang pada PD Ria Mulia Karawang.

d. Membuat laporan penjualan kredit dan laporan piutang PD Ria Mulya Karawang.

e. Merancang system penjualan kredit pada PD Ria Mulia Karawang menggunakan Microsoft Visual Studio 2008 (VB.Net) dan SQL Server 2008 sebagai database nya.

\subsection{Tujuan Penelitian}

Tujuan penelitian pada PD Ria Mulia Karawang adalah untuk mengetahui system penjualan kredit barang yang sedang berjalan pada PD Ria Mulia Karawang dan untuk membuat perancangan system penjualan yang dapat mengatasi masalah pada PD Ria Mulia Karawang berkaitan dengan transaksi penjualan secara kredit.

\section{METODE PENELITIAN}

\subsection{Metode Pengumpulan Data}

Penelitian terdapat teknik pengumpulan data yang merupakan faktor penting dalam keberhasilan suatu penelitian, dimana berkaitan dengan bagaimana cara mengumpulkan data[6]. Adapun dalam penelitian ini penulis menggunakan teknik pengumpulan data sebagai berikut:

a. Wawancara

Wawancara, yaitu mengadakan tatap muka secara langsung dengan berbagai pihak yang terkait[7].

Adapun data yang diperlukan berupa gambaran umum mengenai PD RiaMulia, pengamatan ini dilaksanakan agar penelitian dapat memahami cara kerja sistem yang berjalan dan mempelajari bagaimana prosedur penjualan kredit pada PD Ria Mulia.

b. Observasi

Yaitu melakukan pengamatan secara langsung dengan objek yang diteliti[8], khususnya tentang penjualan kredit barang.

c. Studi kepustakaan

Yaitu Penelitian yang dilakukan di perpustakaan untuk mengumpulkan data-data sekunder yang bersumber pada buku-buku, jurnal ilmiah dan dokumen yang berkaitan dengan masalah yang akan diteliti untuk memperoleh suatu landasan teori[9].

d. Studi dokumentasi

Yaitu Salah satu metode pengumpulan data kualitatif dengan melihat atau menganalisis dokumendokumen[9]. 


\subsection{Metode Pengembangan Sistem}

Pada penelitian ini penulis menggunakan metode pengembangan sistem. System Development Life Cycle (SDLC) dengan model air terjun (waterfall), model air terjun ini menyediakan alur hidup perangkat lunak secara sekuensial atau terurut dimulai dari analisis, desain, pengkodean, pengujian, dan tahap pendukung (Support)[10]. Berikut tahapan waterfall yang digunakan oleh penulis[11].

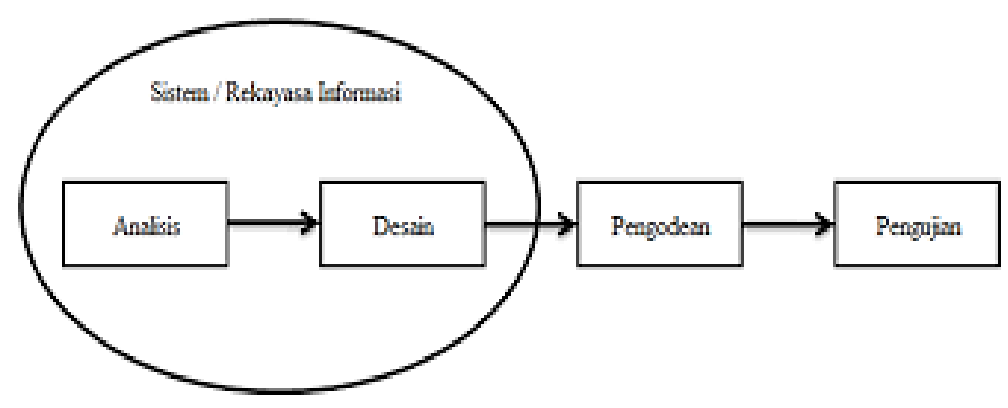

Gambar 1. Model Waterfall

Sumber: Rosa dan Shalahudin[11]

a. Analisis kebutuhan perangkat lunak

Pada tahap ini kegiatan yang akan dilakukan oleh penulis untuk mengumpulkan data-data yang dibutuhkan dalam penelitian.

b. Desain

Metode perancangan yang akan dilakukan oleh penulis dalam menyusun penelitian ini adalah perancangan flow document, perancangan data flow diagram, perancangan kamus data dan perancangan Entity Relationship Diagram. Tahap ini selanjutnya adalah pembuatan bagan terstruktur yang berguna sebagai informasi secara berjenjang dalam bentuk modul-modul dan tahap terakhir adalah pembuatan rancangan masukan dan keluaran pada sistem yang sedang berjalan.

c. Pembuatan Kode Program

Desain harus ditranslasikan ke dalam program perangka lunak. Hasil dari tahap ini adalah program komputer sesuai dengan desain yang telah dibuat pada tahap desain. Penulis akan merancang program dengan bahasa pemograman $\mathrm{Vb}$.Net dengan Database SQL Server.

d. Pengujian

Pengujian fokus pada perangkat lunak secara segi lojik dan fungsional dan memastikan bahwa semua bagian sudah diuji. Hal ini dilakukan untuk meminimalisir kesalahan (error) dan memastikan keluaran yang dihasilkan sesuai dengan yang diinginkan.

\subsection{Pengujian Perangkat Lunak}

Pengujian perangkat lunak adalah cara atau teknik untuk menguji perangkat lunak yang mempunyai mekanisme untuk menentukan data uji yang dapat menguji secara lengkap dan dapat menemukan kemungkinan kesalahan yang tinggi[12]. Pengujian black box adalah pengujian aspek pada sistem tanpa memperhatikan struktur logika perangkat lunak. Metode ini digunakan untuk mengetahui apakah perangkat lunak dapat berfungsi dengan benar. Pengujian black box merupakan metode perancangan data uji yang didasarkan pada spesifikasi perangkat lunak. Data uji dieksekusi pada perangkat lunak dan kemudian keluaran dari perangkat lunak dicek apakah telah sesuai dengan yang diharapkan[13]. Pengujian black box berusaha menemukan kesalahan dalam kategori:

a. Fungsi-fungsi yang tidak benar atau hilang.

b. Kesalahan output antarmuka sistem.

c. Kesalahan dalam struktur data atau akses database eksternal.

d. Kesalahan kinerja sistem.

\section{HASIL DAN PEMBAHASAN}

\subsection{Analisis Prosedur}

Adapun prosedur dalam sistem penjualan kredit adalah sebagai berikut:

a. Customer menyerahkan brosur ke bagian sales.

b. Sales menerima brosur dari customer dan menginput data customer ke database. 
1. jika barang ada sales akan membuat aplikasi persyaratan.

2. jika barang tidak ada maka brosur akan dikembalikan ke customer.

c. Customer mengecek persyaratan dan menyerahkan persyaratan yang sudah lengkap ke bagian sales.

d. Salesmelakukan verifikasi persyaratan yang diajukan oleh customer dan menyerahkan persyaratan tersebut ke bagian pimpinan.

e. Pimpinan menerima persyaratan dan melakukan validasi persyaratan tersebut.

1. Jika persyaratan sudah lengkap dan memenuhi persyaratan maka persyaratan tersebut diserahkan kembali ke bagian sales untuk input data barang.

2. Jika persyaratan masih tidak lengkap dan tidak memenuhi persyaratan maka persyaratan tersebut diserahkan ke bagian sales untuk diserahkan kepada customer.

f. Sales menerima persyaratan yang tidak lengkap dari pimpinan dan menyerahkan persyaratan tersebut ke customer.

g. Sales menerima persyaratan yang sudah lengkap dari pimpinan dan menginput data barang dan input kreditur ke database.

h. Sales mencetak data kreditur dan menyerahkan kartu tagihan ke customer dan menyerahkan data kreditur ke bagian penagihan.

i. $\quad$ Customer menerima kartu tagihan dari sales.

j. Bagian penagihan menerima data kreditur dari bagian sales.

Berikut adalah flowchart prosedur penjualan kredit barang pada PD Ria Mulia Karawang

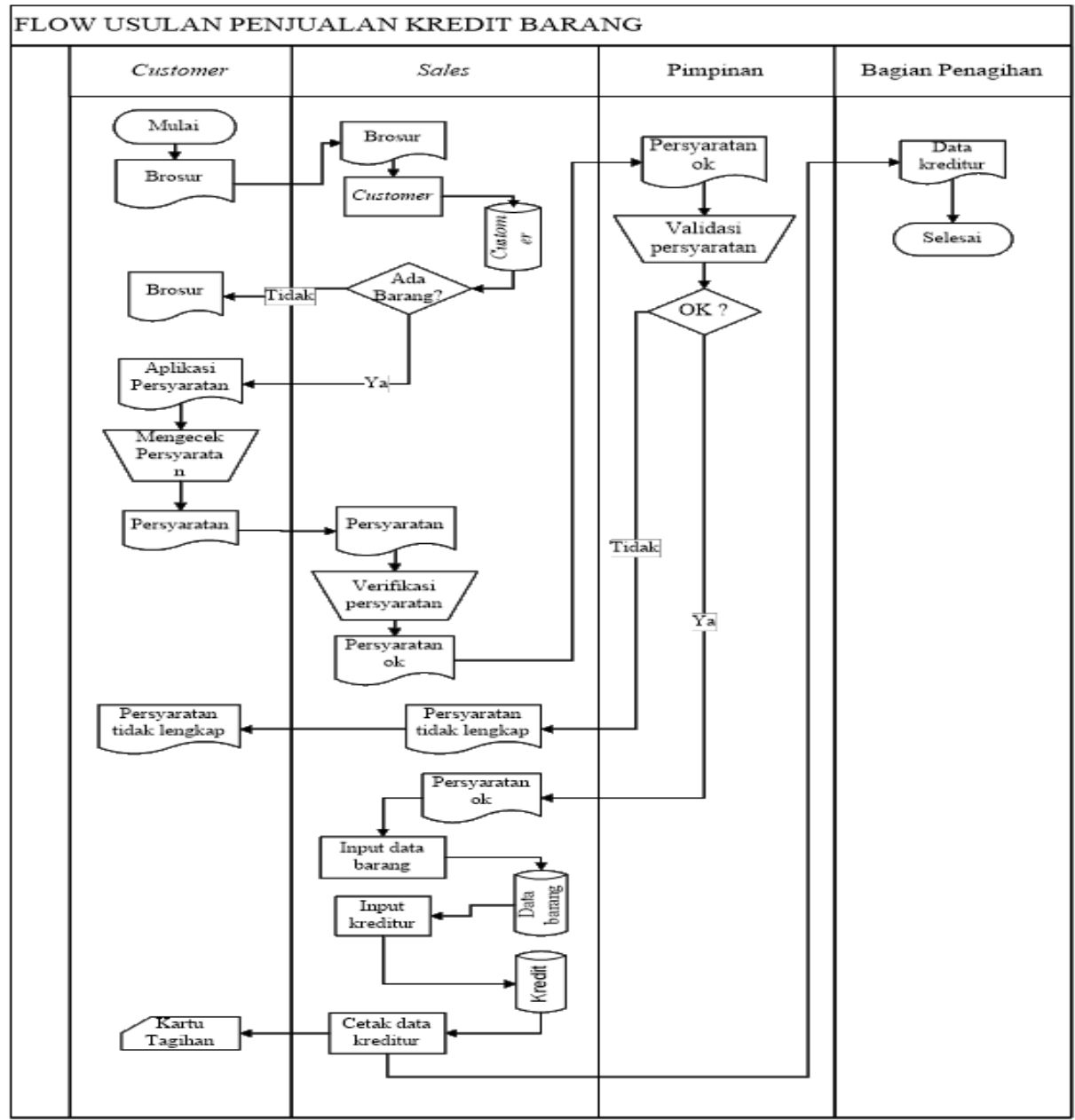

Gambar 2. FlowSystem Penjualan Kredit Barang

\subsection{Desain Perancangan Sistem}

Desain perancangan sistem merupakan bagian dari tahapan sistem yang digunakan. Tahapan ini berfokus pada pemodelan alur sistem dan desain antarmuka.

a. Diagram Kontek

Diagram kontek adalah diagram yang menggambarkan input dan output dalam suatu sistem. Berikut adalah gambar diagram kontek aplikasi penjualan kredit barang. 


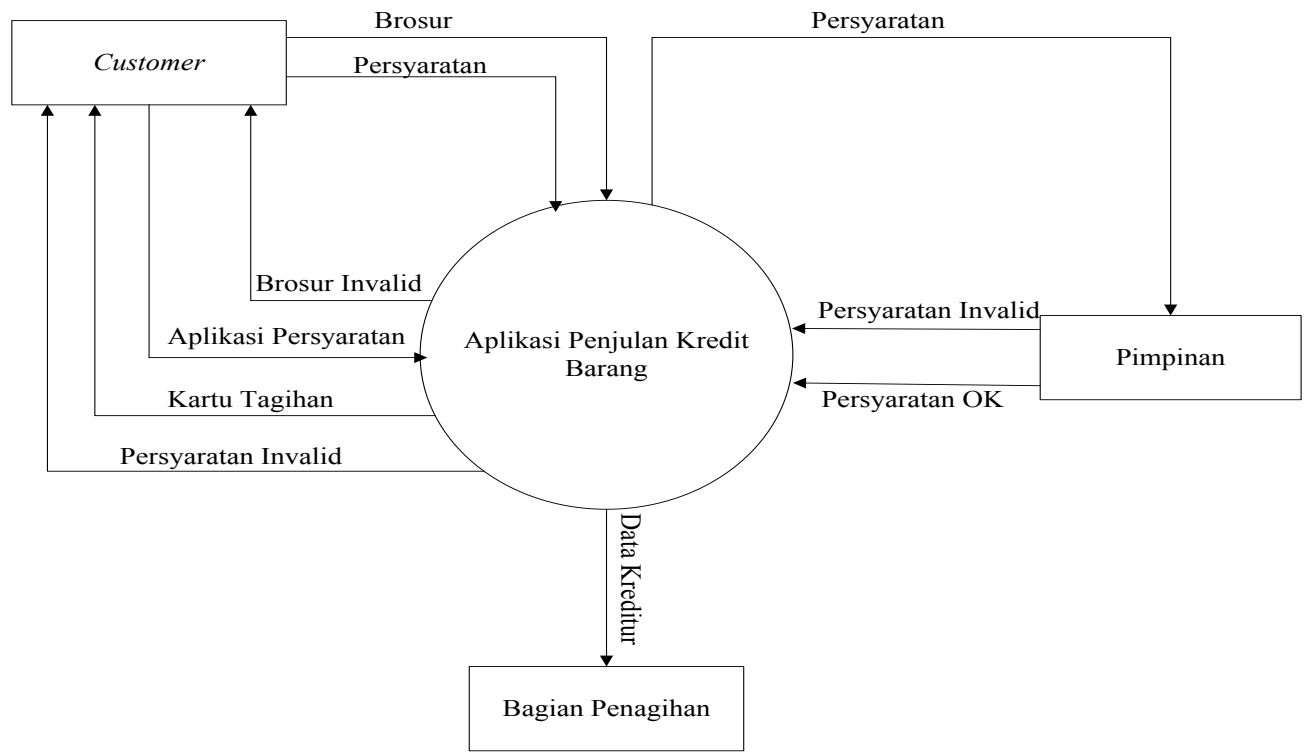

Gambar 3. Diagram Kontek

b. Diagram Overview

Pada DFD Overview, akan dijelaskan mengenai proses-proses yang terjadi dalam sistem ini, yaitu proses cek barang dan harga dari customer, proses pengiriman persyaratan ke pimpinan, dan proses input data customer dan kreditur.

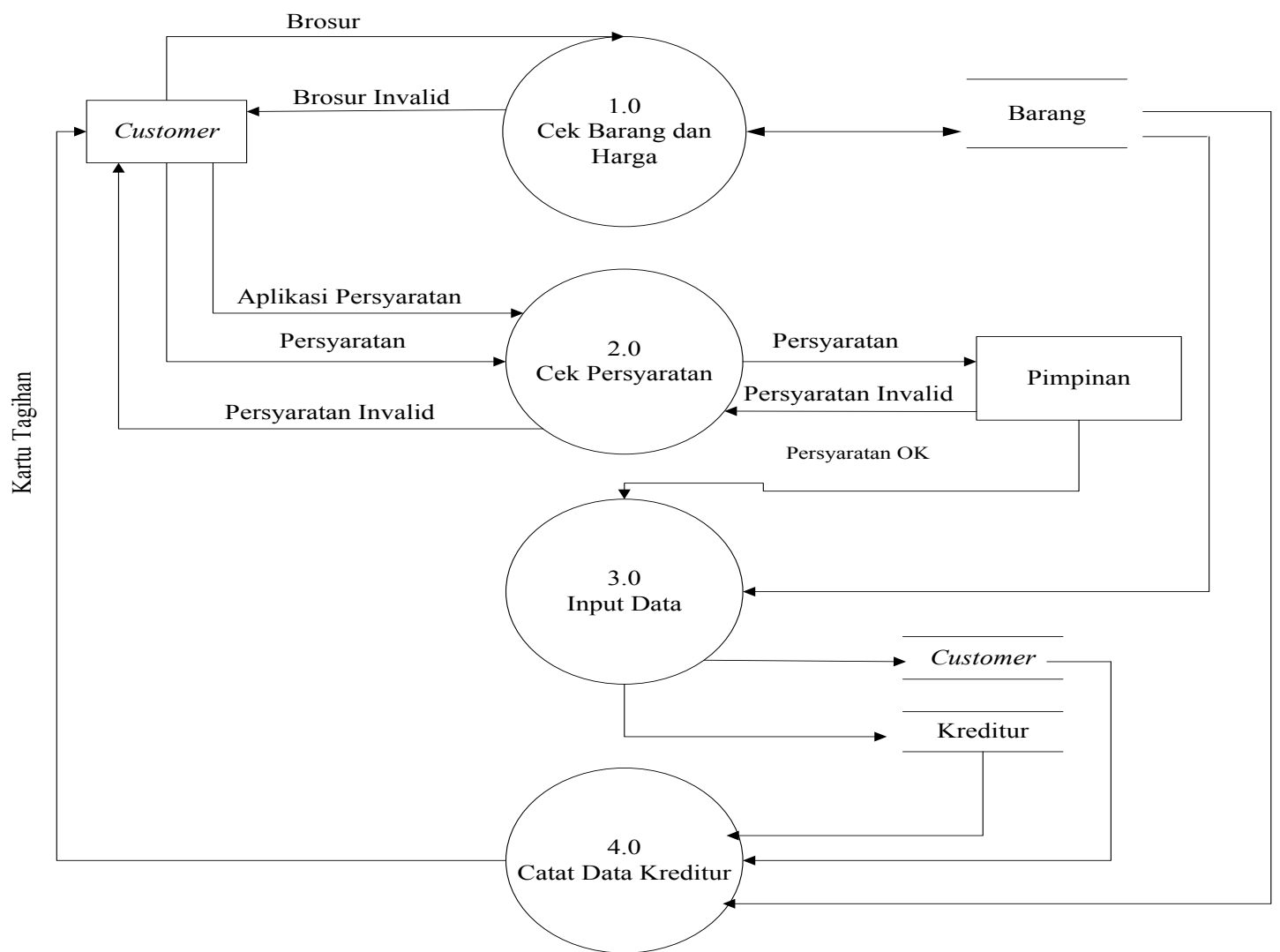

c. Diagram Rinci

Gambar 4. Diagram Overview

Diagram rinci adalah diagram yang memungkinkan proses yang ada di diagram nol lebih diperinci lagi. Berikut adalah usulan diagram rinci pada PD Ria Mulia Karawang. 
1. Diagram rinci proses 1.0

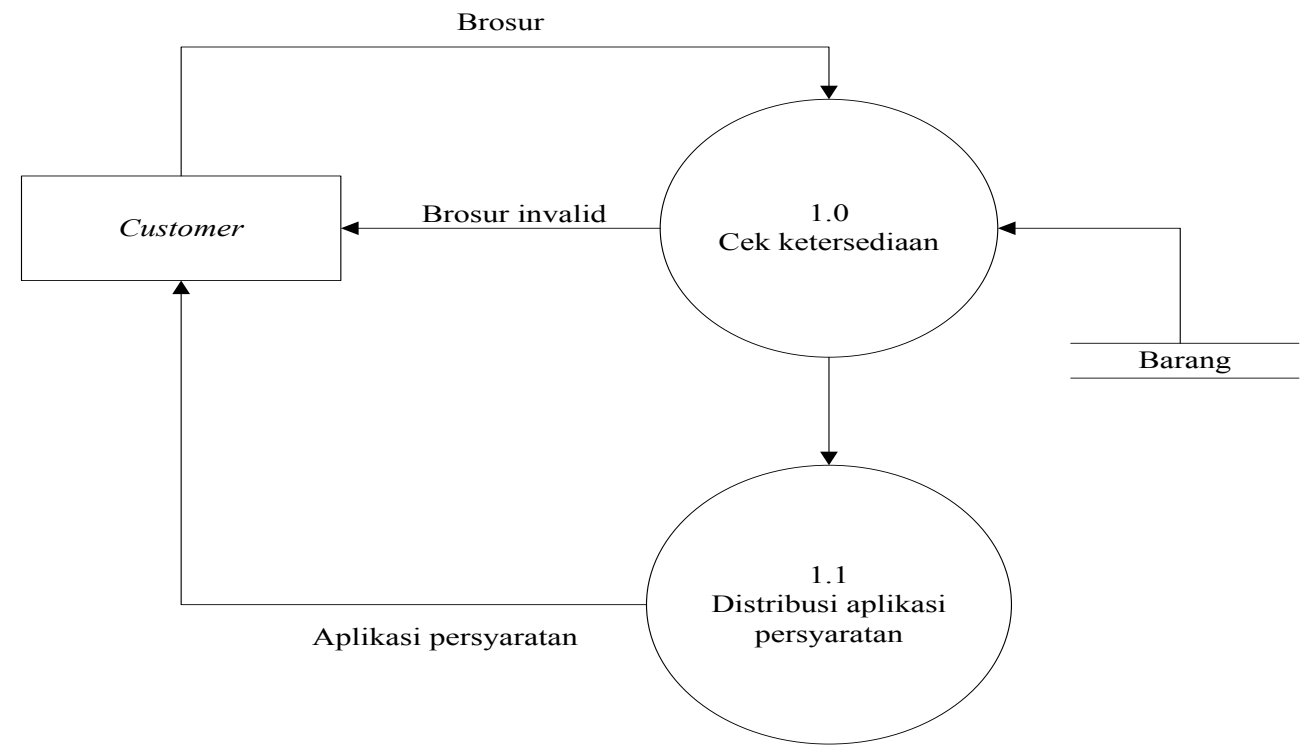

Gambar 5. Diagram Rinci Proses 1.0

2. Diagram rinci proses 2.0

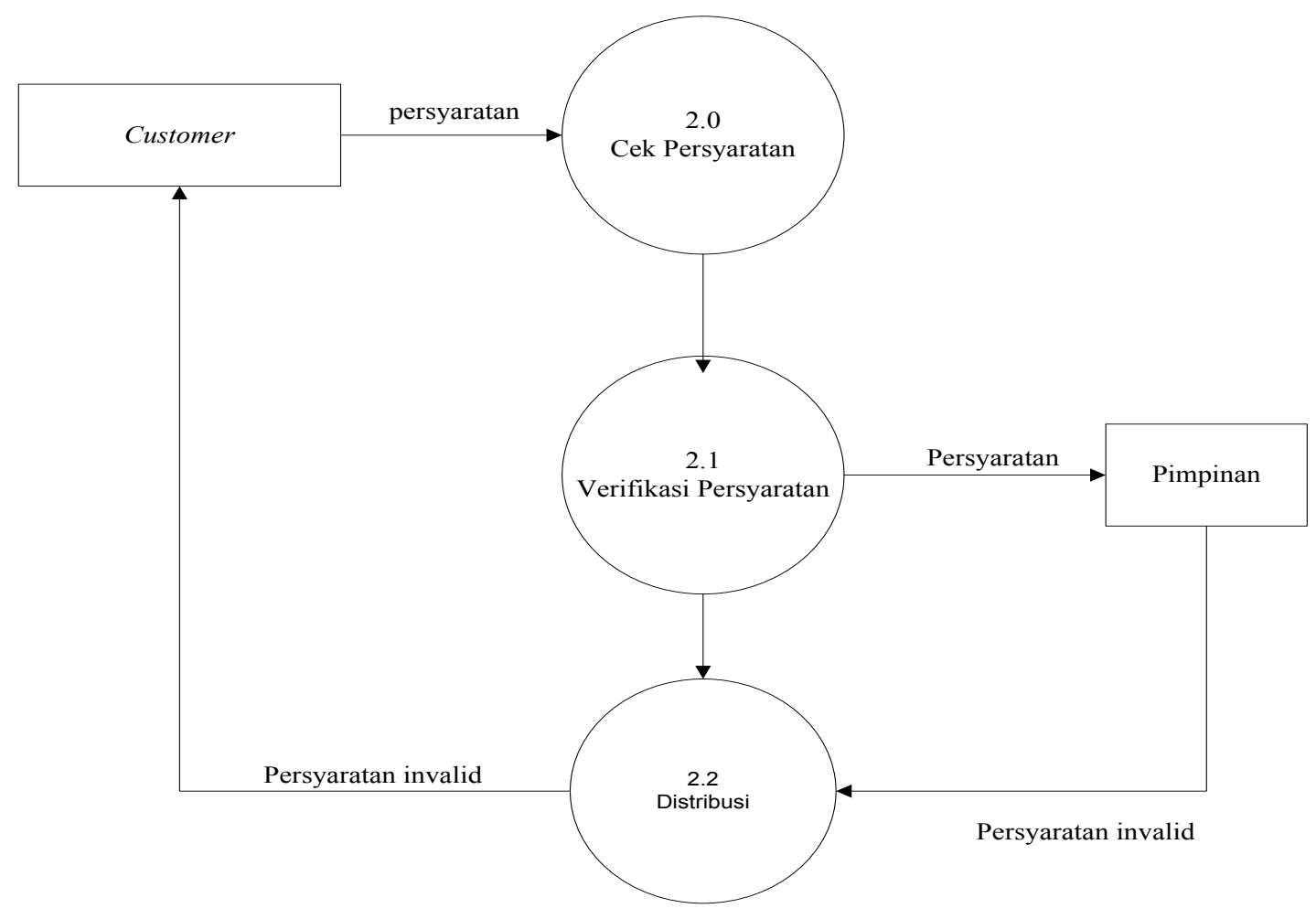

Gambar 6. Diagram Rinci Proses 2.0 
3. Diagram rinci proses 3.0

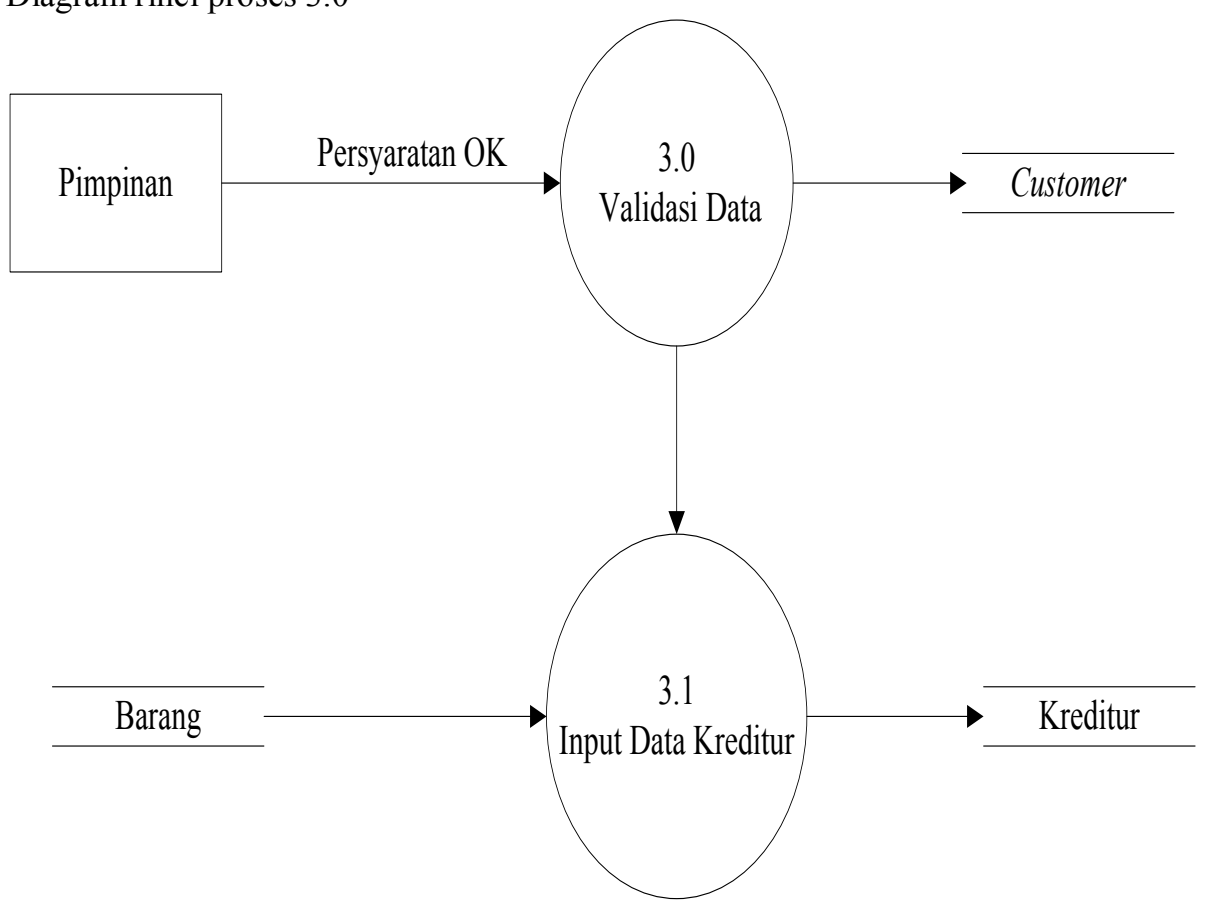

Gambar 7. Diagram Rinci Proses 3.0

d. EntityRelationship Diagram (ERD)

Entity Relationship Diagram (ERD) adalah diagram yang menggambarkan relasi atau hubungan antar entitas[14]. Adapun gambar Entity Relationship Diagram adalah sebagai berikut.

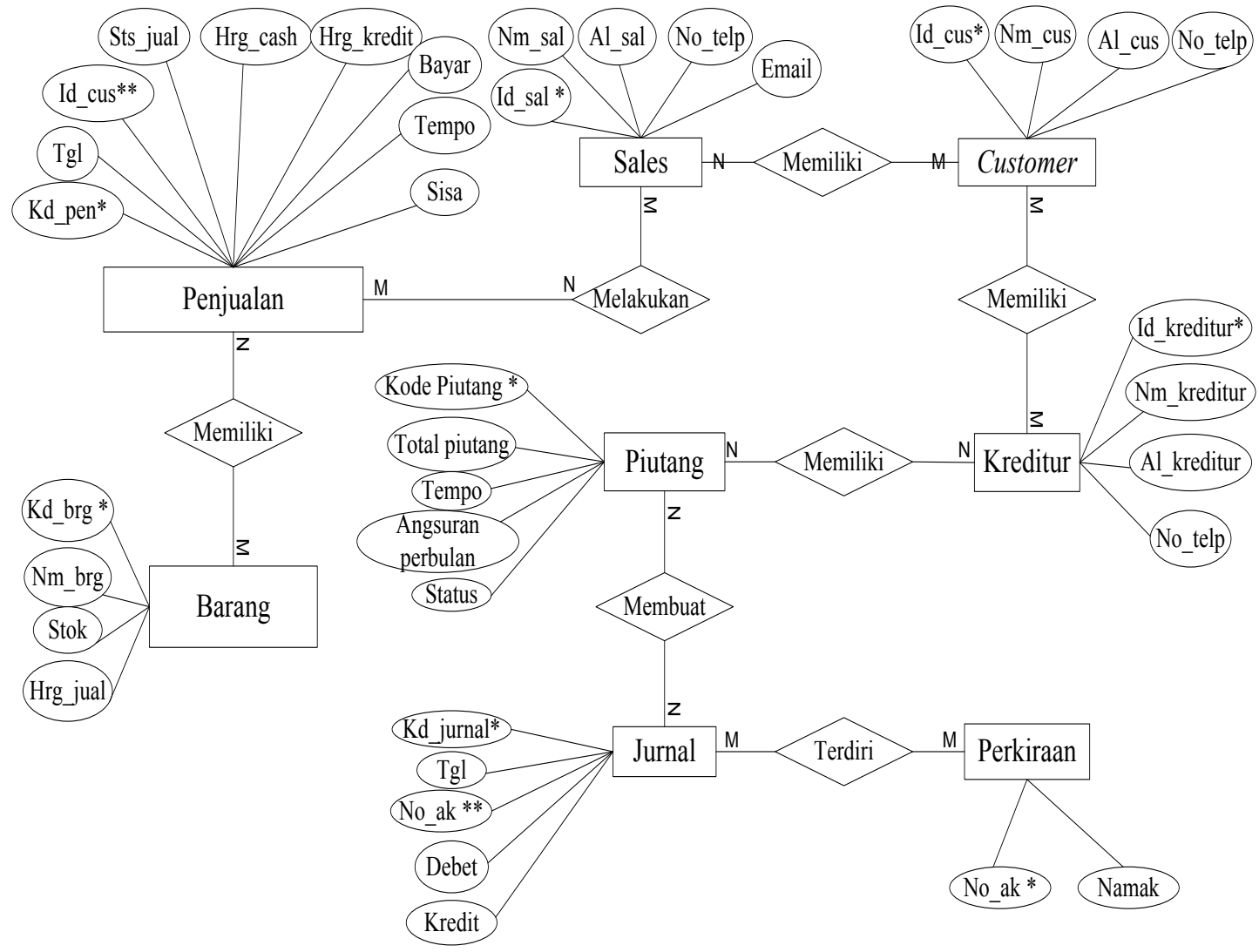

Gambar 8. Entity Relationship Diagram (ERD) 


\subsection{Implementasi Sistem}

a. Tampilan Login

Pada layar "Login" user harus memasukan username dan password terlebih dahulu. Apabila username atau password yang dimasukan tidak benar, maka pada saat memilih login tidak dapat login ke tampilan layar berikutnya. Tetapi apabila username dan password yang dimasukan benar, maka pada saat memilih login akan muncul layar menu utama. Apabila memilih cancel, maka akan menutup layar login.

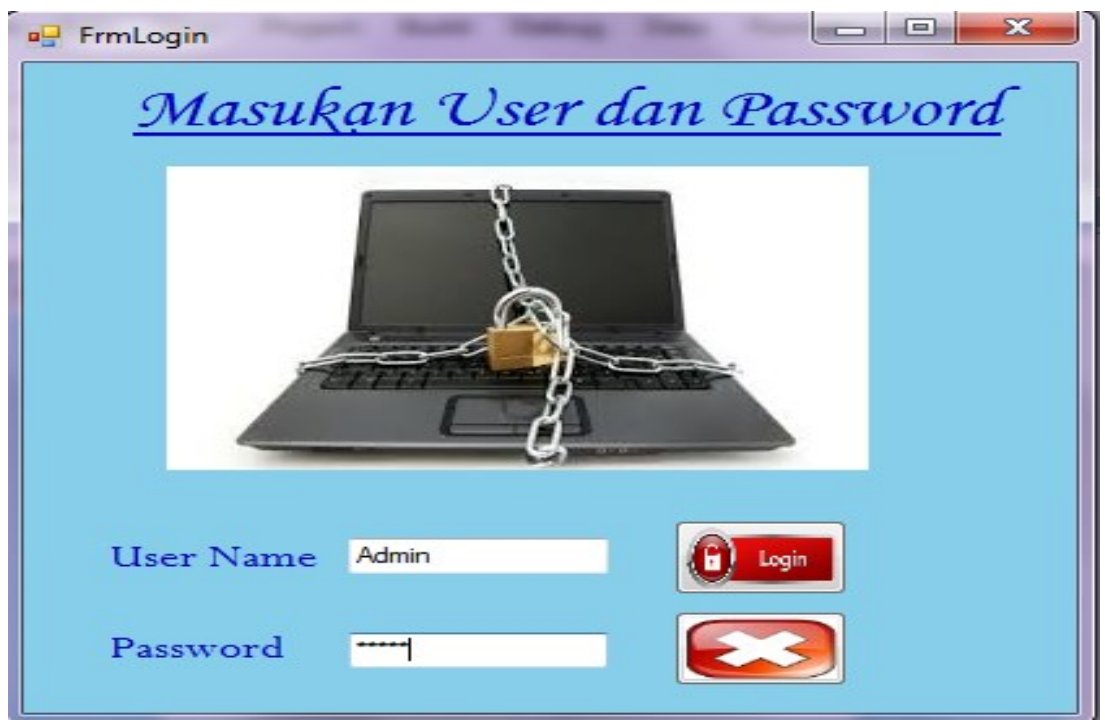

Gambar 9. Tampilan Login

b. Tampilan Menu Utama

Setelah user melakukan login, maka akan muncul tampilan layar menu utama yang terdiri dari file, master, transaksi dan laporan. Jika user akan menginput data maka pilih layar master, layar transaksi untuk user melakukan transaksi dan layar laporan yaitu digunakan untuk menampilkan semua hasil laporan yang telah di input oleh user di layar master dan layar transaksi. Dan layar file untuk menutup layar aplikasi menu utama ini.

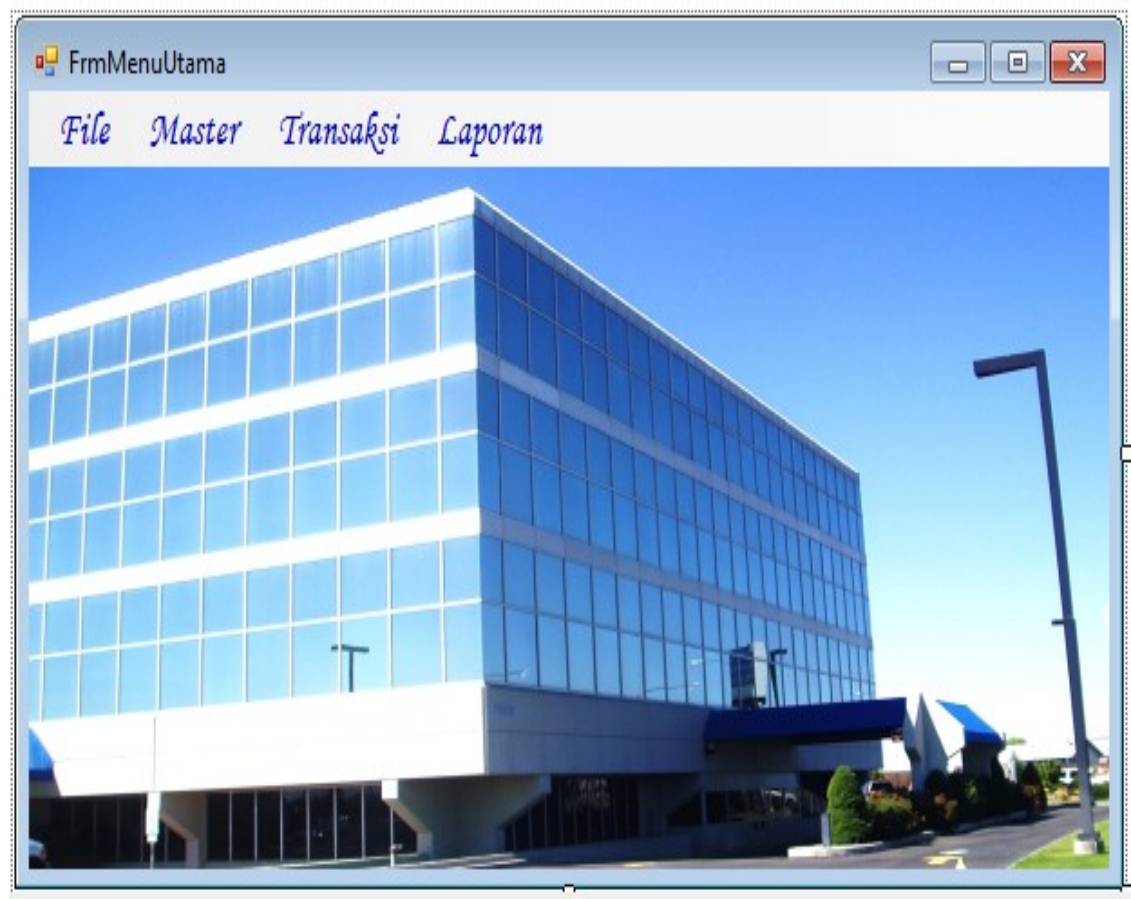

Gambar 10. Tampilan Menu Utama 
c. Tampilan Form Penjualan

Form penjualandigunakan untuk input transaksi penjualan barang baik secara cash maupun secara kredit. Pilih button baru untuk transaksi penjualan baru, jika menginput transaksi penjualan secara kredit ketika data transaksi di simpan maka data transaksi penjualan secara otomatis akan masuk ke form piutang, dan button keluar untuk keluar dari layar aplikasinya.

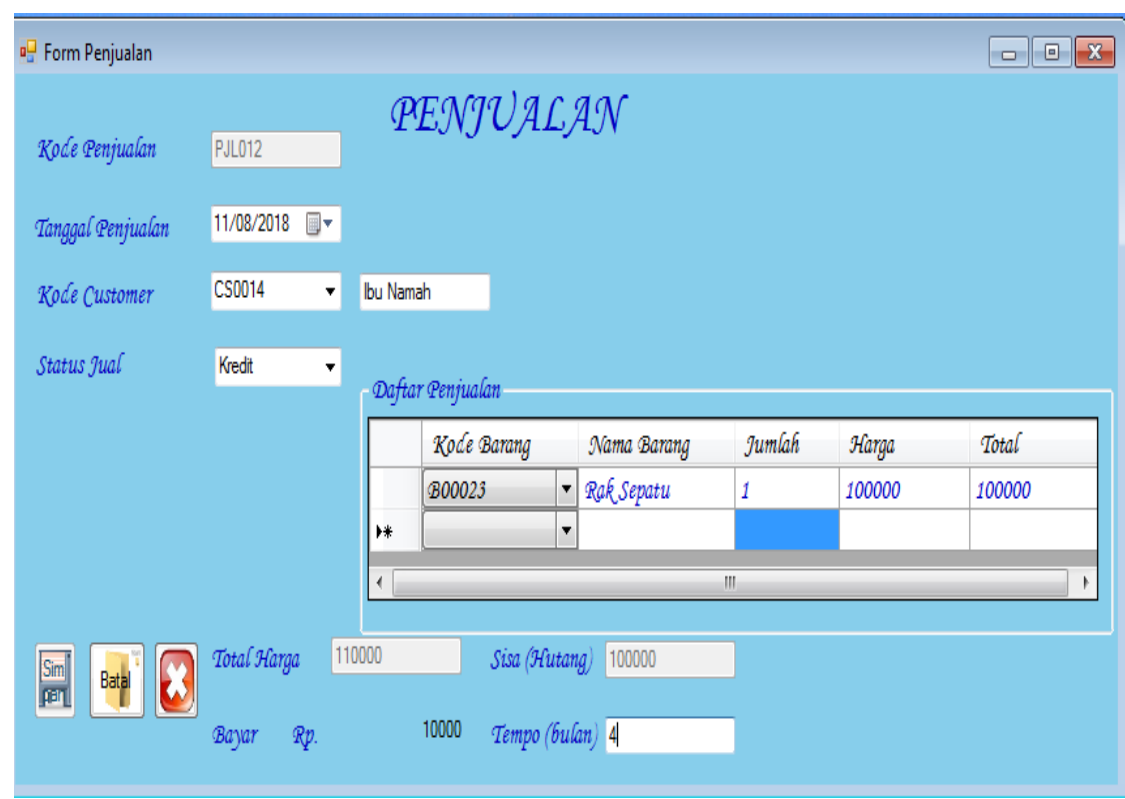

Gambar 11. Tampilan Form Penjualan

d. Tampilan Laporan Penjualan Kredit

Report laporan penjualan kreditdigunakan untuk menampilkan laporan penjualan secara kreditdi perusahaan.

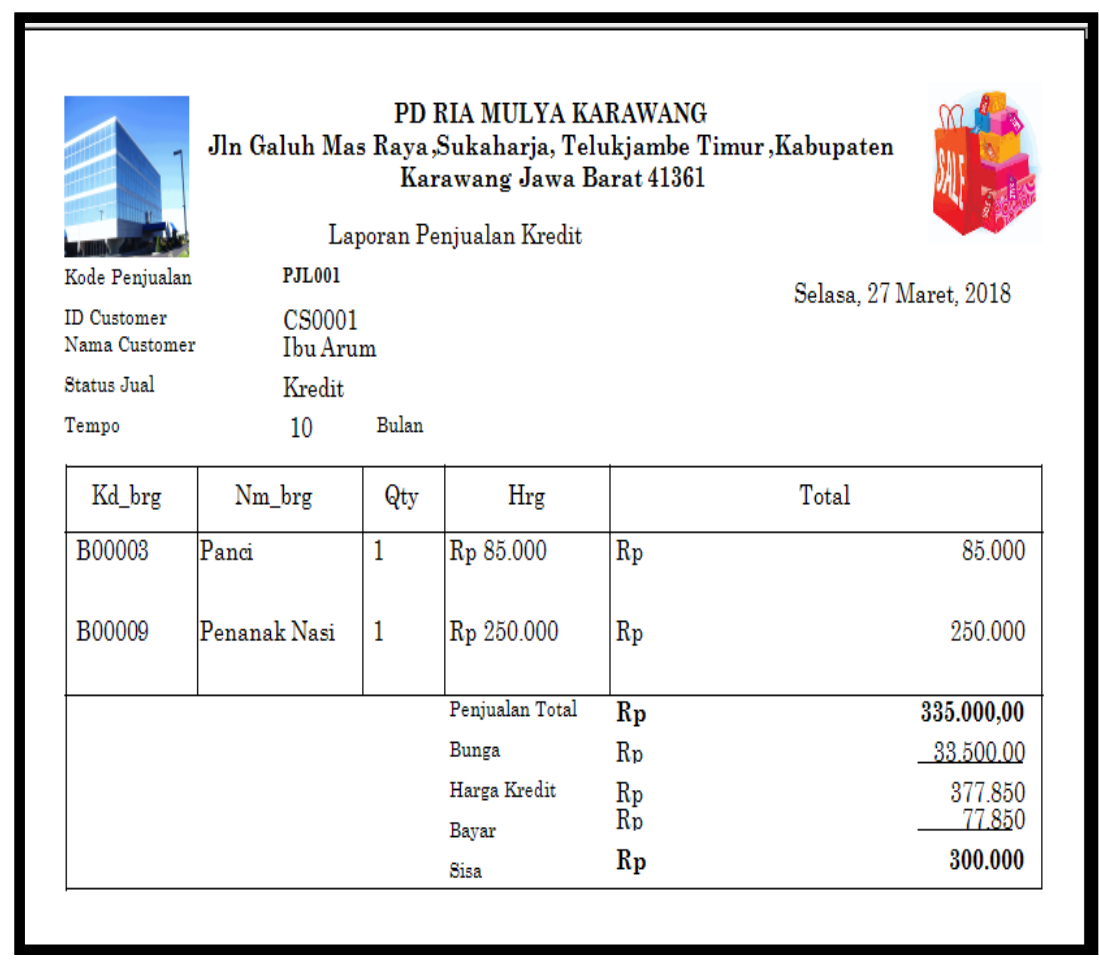

Gambar 12. Tampilan Laporan Penjualan 


\subsection{Pengujian Sistem}

Berikut ini adalah hasil pengujian aplikasi penjualan kredit barang menggunakan metode Black Box.

Tabel 1. Black Box Testing

\begin{tabular}{|c|c|c|c|c|}
\hline No & $\begin{array}{l}\text { Fungsi yang } \\
\text { diuji }\end{array}$ & Cara pengujian & Hasil yang diharapkan & $\begin{array}{c}\text { Hasil } \\
\text { pengujian }\end{array}$ \\
\hline 1 & Form Star Up & $\begin{array}{l}\text { Pada form ini menampilkan } \\
\text { pembukaan awal untuk aplikasi }\end{array}$ & $\begin{array}{l}\text { Menampilkan halaman } \\
\text { pembuka di dalam aplikasi. }\end{array}$ & $\mathrm{OK}$ \\
\hline 2 & Form Login & $\begin{array}{l}\text { Pada from ini menampilkan } \\
\text { halaman login untuk masuk } \\
\text { sebagai admin. }\end{array}$ & $\begin{array}{l}\text { Menampilkan halaman } \\
\text { login dan berhasil masuk ke } \\
\text { dalam aplikasi sebagai } \\
\text { admin.. }\end{array}$ & $\mathrm{OK}$ \\
\hline 3 & $\begin{array}{l}\text { Form } \quad \text { Menu } \\
\text { Utama }\end{array}$ & $\begin{array}{l}\text { Setelah berhasil masuk } \\
\text { menampilkan halaman menu } \\
\text { utama. }\end{array}$ & $\begin{array}{l}\text { Menampilkan halaman } \\
\text { menu utama. }\end{array}$ & $\mathrm{OK}$ \\
\hline 4 & Form Customer & Memilih toolbarcustomer. & $\begin{array}{lr}\text { Menampilkan } & \text { form } \\
\text { customer, mengisi, } & \text { mengedit, cari, dan } \\
\text { menghapus datacustomer. }\end{array}$ & $\mathrm{OK}$ \\
\hline 5 & Form Barang & Memilih toolbarbarang. & $\begin{array}{l}\text { Menampilkan form barang, } \\
\text { mengisi, mengedit, cari dan } \\
\text { menghapus data barang. }\end{array}$ & $\mathrm{OK}$ \\
\hline 6 & Form Sales & Memilih toolbar sales & $\begin{array}{l}\text { Menampilkan form sales, } \\
\text { mengisi, mengedit, cari, dan } \\
\text { menghapus data sales. }\end{array}$ & $\mathrm{OK}$ \\
\hline 7 & Form Kreditur & Memilih toolbar kreditur & $\begin{array}{l}\text { Menampilkan form } \\
\text { kreditur, } \\
\text { menyimpan dan menghapus } \\
\text { data kreditur. }\end{array}$ & $\mathrm{OK}$ \\
\hline 8 & Form Penjualan & Memilih toolbar penjualan. & $\begin{array}{l}\text { Menampilkan form } \\
\text { penjualan, mengisi, } \\
\text { menyimpan, mencari data } \\
\text { dan menghapus data } \\
\text { penjualan. }\end{array}$ & $\mathrm{OK}$ \\
\hline 9 & Form Piutang & Memilih toolbar piutang. & $\begin{array}{l}\text { Menampilkan form piutang, } \\
\text { dan menyimpan data } \\
\text { piutang. }\end{array}$ & $\mathrm{OK}$ \\
\hline 10 & Form Angsuran & Memilih toolbar form ang. & $\begin{array}{ll}\text { Menampilkan form ang, } \\
\text { mengisi, dan menyimpan } \\
\text { data angsuran. }\end{array}$ & $\mathrm{OK}$ \\
\hline 11 & Form Retur & Memilih toolbar form retur. & $\begin{array}{l}\text { Menampilkan form retur, } \\
\text { menginput retur barang, dan } \\
\text { meyimpan data retur } \\
\text { barang. }\end{array}$ & $\mathrm{OK}$ \\
\hline 12 & $\begin{array}{ll}\text { Form } & \text { Laporan } \\
\text { Jurnal } & \end{array}$ & $\begin{array}{l}\text { Memilih toolbar laporan } \\
\text { jurnal. }\end{array}$ & $\begin{array}{l}\text { Menampilkan hasil laporan } \\
\text { data-data dari keseluruhan } \\
\text { transkasi yang melalui tabel } \\
\text { akun kas. }\end{array}$ & $\mathrm{OK}$ \\
\hline 13 & $\begin{array}{l}\text { Form Laporan } \\
\text { Penjualan }\end{array}$ & $\begin{array}{l}\text { Memilih toolbar laporan } \\
\text { penjualan. }\end{array}$ & $\begin{array}{l}\text { Menampilkan hasil laporan } \\
\text { data-data dari keseluruhan } \\
\text { transaksi penjualan secara } \\
\text { cash dan kredit. }\end{array}$ & $\mathrm{OK}$ \\
\hline 14 & $\begin{array}{ll}\text { Form } & \text { Laporan } \\
\text { Piutang } & \end{array}$ & $\begin{array}{l}\text { Memilih toolbar laporan } \\
\text { piutang. }\end{array}$ & $\begin{array}{l}\text { Menampilkan hasil laporan } \\
\text { data-data dari keseluruhan } \\
\text { transaksi penjualan secara } \\
\text { kredit. }\end{array}$ & $\mathrm{OK}$ \\
\hline
\end{tabular}




\begin{tabular}{|c|l|l|l|c|}
\hline 15 & $\begin{array}{l}\text { Form Laporan } \\
\text { Angsuran }\end{array}$ & $\begin{array}{l}\text { Memilih toolbar laporan } \\
\text { angsuran. }\end{array}$ & $\begin{array}{l}\text { Menampilkan hasil laporan } \\
\text { data-data dari keseluruhan } \\
\text { transaksi pembayaran } \\
\text { angsuran. }\end{array}$ & OK \\
\hline 16 & $\begin{array}{l}\text { Form Laporan } \\
\text { Data Barang }\end{array}$ & $\begin{array}{l}\text { Memilih toolbar laporan data } \\
\text { barang. }\end{array}$ & $\begin{array}{l}\text { Menampilkan } \\
\text { laporandata barang. }\end{array}$ & OK \\
\hline 17 & $\begin{array}{l}\text { Form Laporan } \\
\text { Data Sales }\end{array}$ & $\begin{array}{l}\text { Memilih toolbar laporan data } \\
\text { sales. }\end{array}$ & $\begin{array}{l}\text { Menampilkan laporan data } \\
\text { sales perusahaan. }\end{array}$ & OK \\
\hline 18 & $\begin{array}{l}\text { Form Laporan } \\
\text { Retur }\end{array}$ & $\begin{array}{l}\text { Memilih toolbar laporan retur } \\
\text { penjualan. }\end{array}$ & $\begin{array}{l}\text { Menampilkan laporan data } \\
\text { retur penjualan barang. }\end{array}$ & OK \\
\hline
\end{tabular}

\section{KESIMPULAN}

Berdasarkan penelitian yang dilakukan, maka penulis mengambil kesimpulan sebagai berikut:

a. Dengan adanya sistem komputerisasi yang terintegritas pada sistem penjualan kredit barang di PD Ria Mulya Karawang, dapat membantu bagian yang terkait di perusahaan tersebut untuk mempermudah pengolahan data yang dibutuhkan perusahaan.

b. Agar sistem penjualan kredit barang yang dibuat dapat berjalan dengan baik, diharapkan user yang mengoperasikan sistem penjualan kredit barang tersebut memiliki pengetahuan dan kemampuan dalam pengoperasian sistem tersebut, atau dapat pula mengadakan pelatihan bagi admin dalam bidang komputer guna meningkatkan kemampuan admin dalam mengoperasikan komputer.

c. Untuk menghindari kehilangan atau kerusakan data penting, maka diperlukan Backup Database agar pada saat data tersebut dibutuhkan masih tersedia.

d. Pengujian aplikasi dengan menggunakan teknik black box testing dengan metode equivalence partitioning yang diujikan terhadap aplikasi yang berjalan memberikan hasil pengujian yang baik sesuai dengan harpan.

\section{UCAPAN TERIMAKASIH}

Penulis mengucapkan terima kasih kepada seluruh pihak yang telah memberikan data yang diperlukan oleh penulis dan waktu yang diluangkan untuk membantu penulis dalam penelitian ini, serta dukungan keluarga kepada penulis dalam penyelesaian penelitian ini..

\section{REFERENCES}

[1] "PENGARUH VOLATILITAS PENJUALAN, VOLATILITAS ARUS KAS OPERASI, DAN HUTANG TERHADAP PERSISTENSI LABA,” J. ASET (Akuntansi Riset), 2020.

[2] D. Mulyanti, “Manajemen Keuangan Perusahaan,” J. Ilm. Akunt., 2017.

[3] W. J. Lestari, M. Asfi, and A. Setiawati, "Sistem Pengendalian Internal Atas Piutang Menggunakan Metode Analisis Umur Piutang (Aging Schedule) Pada CV. AGS'NIE," J. Digit, 2020.

[4] R. A. Nurafika, "Pengaruh Perputaran Kas, Perputaran Piutang, Perputaran Persediaan Terhadap Profitabilitas Pada Perusahaan Semen,” J. Akunt. DAN BISNIS J. Progr. Stud. Akunt., 2018.

[5] "Pengaruh Tingkat Perputaran Aktiva Lancar, Perputaran Modal Kerja, Likuiditas, Ukuran Perusahaan, Pertumbuhan Koperasi Terhadap Profitabilitas," E-Jurnal Akunt., 2018.

[6] M. \& A. Sari, "Penelitian Kepustakaan (Library Research) dalam Penelitian Pendidikan IPA,” Nat. Cience J. Penelit. Bid. IPA dan Pendidik. IPA, 2020.

[7] K. Koentjaraningrat, "Metode-metode Wawancara," Antropol. Indones., 2019.

[8] O. R. Arsyad, Kurnia, and P. Kartika, "Pengertian Observasi," Ranc. Bangun Alat Pengaman Brankas Menggunakan Sens. Sidik Jari Berbas. Arduino, 2021.

[9] P. Yaniawati, "Penelitian Studi Kepustakaan,” Penelit. Kepustakaan (Liberary Res., 2020.

[10] M. Bulman, "SDLC - Waterfall Model,” Indep., 2017. 
[11] A. . Rosa and M. Shalahuddin, "Model Sdlc,” Informatika Bandung. 2018.

[12] T. S. Jaya, "Pengujian Aplikasi Dengan Metode Blackbox Testing Boundary Value Analysis (Studi Kasus: Kantor Digital Politeknik Negeri Lampung)," J. Inform. J. Pengemb. IT, 2018.

[13] R. Parlika, T. A. Nisaa, S. M. Ningrum, and B. A. Haque, "Studi Literatur Kekurangan dan Kelebihan Pengujian Black Box," Teknomatika, 2020.

[14] A. M. Yusuf and N. Dini, "TETAP MENGGUNAKAN METODE GARIS LURUS BERBASIS VB . NET PADA CV GINANJAR SEJAHTERA MANDIRI KARAWANG,” vol. 16, pp. 38-45, 2021. 